\title{
The Development of "Lianala" Game Device for Early Childhood
}

\author{
Cynthia Elfadinaria, Mustaji, Rachma Hasibuan \\ Universitas Negeri Surabaya \\ Surabaya, Indonesia \\ cynthia.pascas2@gmail.com
}

\begin{abstract}
The purpose of this study is to produce a "lianala" game device that is suitable to be used to stimulate gross and cognitive motor development of early childhood. The tools developed are "lianala" game devices consisting of (1) "lianala" games, (2) APE "lianala", (3) "lianala" game guide books, (4) Weekly Learning Implementation Plans and Daily Learning Implementation Plans The game "lianala", (5) Rating of the game "lianala". The development procedure uses the Dick and Carey model. The feasibility of the "lianala" game device is tested by using the Guttman scale from several stages, namely the test of material experts in gross and cognitive motor development, game expert testing, individual trials and small group trials. The results of the trial show that the "lianala" game device is appropriate to be used to stimulate gross and cognitive motor development of early childhood.
\end{abstract}

Keywords- Game Device; Rough Motoric; Cognitive; Early Childhood.

\section{INTRODUCTION}

Early Childhood (AUD) is a period in which children have the privilege of behaving. The characteristics of AUD are (1) unique, (2) egocentric, (3) active and energetic, (4) curiosity and enthusiasm towards various things, (5) explorative and adventurous, (6) spontaneous, (7) rich in fantasy, (8) still easily frustrated, (9) lack of consideration in doing things, (10) short attention, (11) passion for learning and much to learn from experience [1].

Children aged 4-5 years have characteristics associated with, (1) physical development, its relation to children aged 45 years old i.e. children who are active in doing various useful activities to develop small muscles and large muscles, (2) language development, i.e. the child understands the conversation of others and is able to convey what is in his/ her mind, (3) the cognitive development, the curiosity of the extraordinary 4-5 years old child to the environment, something that the child sees will be asked to the adults, (4)) the form of the child's game is still individual, the type of game of 4-5 years old children is usually presented for individual, although the playing activity is done together [2].

There are characteristics of AUD learning among others, (1) children can only learn if they are not separated from the need to play, meaning the nature of AUD is playing because through it the children will enjoy the learning process, (2) children can only learn if the play is assisted by the concrete game tools, in the learning process of AUD that is still a concrete to the abstract required game tools so that the real value of education can be achieved, (3) children can only learn if their feelings are protected and save, the conditions that children need in learning with the atmosphere which is safe and comfortable so that children feel protected, (4) children can only learn if they are free from the adult coercion, in learning process the children freely choose the activities without any coercion [3]. The adults' activities are accompanying the children learning process by motivating or stimulating them in the playing activities.

The game device is playing a very important part in children daily activities presented in the form of toys or materials for kids in particular. The adults provide a variety of play tools to encourage the implementation of different types of games, as the child's game changes according to the set-up device of an adult.

Common problems faced by the early childhood teachers are planning the learning process with a game and providing an innovative game tool in presenting material for prospective small athletes on aspects of gross and cognitive motor development so that children experience obstacles in my theme material, sub-themes become prospective small athletes. Permendikbud Number 146 of 2014 concerning PAUD Curriculum explains basic competencies 3.3-4.3 that the early age children are able to recognize body members that is moving and using body members for gross motoric development with hopes of fostering early childhood athletes so that aspects of gross motoric and cognitive development of children will be stimulated optimally.

The concept of montessori in children's cognitive understanding through three ways, namely (1) concrete, (2) abstract, and (3) both concrete and abstract. Decaprio (2013) states that gross motor is moving the limbs that are affected by self-maturation by using large muscles [4].

Therefore, the researchers take action to develop a game device that is needed by the teacher in planning the learning process by using the game "Lianala". It stands for circle of color numbers and balls with the theme of candidates for small athletes for early childhood.

\section{METHOD}

The method used in this study is the Dick and Carey development model (2015) through 10 stages, namely (1) assess the need to identity goals (2) conduct the instructional analysis (3) analyze the learner and contexts (4) write the performance objective (5) develop the criterion referenced test items (6) develop the instructional strategy (7) develop and select the instructional materials (8) design and conduct the 
formative evaluation of instruction (9) revise the instruction (10) design and conduct the summative evaluation [5]. This development research carries out 8 stages, because to see the feasibility of the product being developed. This development product is tested through several stages, namely: (1) material expert validation (2) game expert validation (3) individual trials and (4) small group trials. Individual trial subjects are 3 children and a small group consists of 6 children are carried out at TK Qurota A'yun 01 Aisyah Pekalongan City, Central Java. Subjects Field trials are carried out at Flamboyan Pekalongan Kindergarten in Central Java for children in group A. The group consist of 30 children, 15 A1 kindergarten children and 15 kindergarten children A2. A1 plays as the experimental group and A2 as the control group. Group retrieval is formed by the researchers randomly. The data are collected to determine the feasibility of the "lianala" game device, namely through the results of the first stage evaluation data from the results of validator material experts and game expert validators as well as individual trial results data, small group trials and field trials. The instruments used are observation instruments, interviews and questionnaires. The data are analyzed by using qualitative descriptive analysis.

\section{RESULTS AND DISCUSSION}

The development of the "lianala" game equipment produced several products, namely: (1) "lianala" game, (2) APE "lianala", (3) "lianala" game guide book, (4) Weekly Learning Implementation Plan (RPPM) and Plan Daily Learning Implementation (RPPH) game "lianala", (5) assessment of the "lianala" game.

1. The game "lianala" stands for the word circle of the ball's color number. The step of this game is using parallel playing methods from Mildred Parten. The lianala game is a specially designed game play development and educational game tool (APE) that used to gain perfection of game development products in stimulating gross and cognitive motor development of 4-5 years old. The game "lianala" has 3 stages of play i.e. start, activity and finish. The step game of "lianala" starts by playing roulette color, kicking the ball as the activity 1, play bowling as the activity 2, playing boana as the activity 3 , playing zigzag zone as the activity 4 and end by playing the ball medal.

2. APE "lianala" is a game tool designed specifically to stimulate gross and cognitive motor development. Type of APE "lianala":

TABLE 1 APE

\begin{tabular}{|c|l|l|}
\hline No & Nama APE & \multicolumn{1}{|c|}{ Spesifikasi produk } \\
\hline 1 & Roulette colour & $\begin{array}{l}\text { Height of pole } 100 \mathrm{~cm}, \\
\text { diameter roulette } 50 \mathrm{~cm}\end{array}$ \\
\hline 2 & Kicking the ball & $\begin{array}{l}\text { Goal } 70 \mathrm{~cm} \times 52 \mathrm{~cm} \times 54 \mathrm{~cm}, \\
\text { Diameter of the ball } 15 \mathrm{~cm}, \\
\text { Distance kicked the ball } 150 \mathrm{~cm}\end{array}$ \\
\hline 3 & Bowling & $\begin{array}{l}\text { The pin height is } 28.5 \mathrm{~cm} \\
\text { Ball diameter } 10 \mathrm{~cm} \\
\text { Throw distance } 140 \mathrm{~cm}\end{array}$ \\
\hline
\end{tabular}

\begin{tabular}{|c|l|l|}
\hline No & \multicolumn{1}{|c|}{ Nama APE } & \multicolumn{1}{c|}{ Spesifikasi produk } \\
\hline 4 & Boana & $38 \mathrm{~cm} \times 23 \mathrm{~cm} \mathrm{x} 80 \mathrm{~cm}$ \\
\hline 5 & Zigzag zone & Diameter $40 \mathrm{~cm}$ \\
\hline 6 & The ball medal & $\begin{array}{l}\text { The length of the rope is } 80 \mathrm{~cm} \\
\text { Ball } 6 \mathrm{~cm} \\
\text { Medal place } 30 \mathrm{~cm}\end{array}$ \\
\hline 7 & Koin "lianala" & $\begin{array}{l}\text { Diameter } 7,5 \mathrm{~cm} \\
\text { Place the coin diameter of } 19.5 \\
\mathrm{~cm}\end{array}$ \\
\hline
\end{tabular}

3. The "lianala" game guide for teachers and children is a book designed as a guideline for the use of "lianala" games.

4. RPPM and RPPH game "lianala" is a weekly and daily learning exercise plan as a guide in the game "lianala".

5. The "lianala" game rating is used as an evaluation after performing the game "lianala" to stimulate gross and cognitive motor development.

The validation results of game and game experts show that the "lianala" game device consisting of "lianala" games, APE "lianala", "lianala" game guides for teachers and children, RPPM and RPPH game "lianala", game rating "lianala" is worth to be used to stimulate gross and cognitive motor as the development of children aged 4-5 years old.

\section{CONCLUSION}

The "lianala" game device consists of "lianala" games, APE "lianala", "lianala" game manuals for teachers and children, RPPM and RPPH game "lianala", game rating "lianala". The game theme "lianala" is a good candidate for small athletes. The validation results of the material experts and the game "lianala" deserve to be used to stimulate gross and cognitive motor development of children aged 4-5 years old.

\section{References}

[1] M. Fadlillah, Desain Pembelajaran PAUD: Tinjauan Teoritik \& Praktik, 2016.

[2] S. Susanto, Pendidikan Anak Usia Dini, Jakarta Citra Pendidik, 2002.

[3] E. Y. Haenilah, Kurikulum dan pembelajaran PAUD, Yogyakarta Media Akad, 2015.

[4] V. D. Paramita, Jatuh Hati pada Montessori. Bentang B first, 2017.

[5] W. Dick, "The Dick and Carey model: Will it survive the decade?," Educ. Technol. Res. Dev., vol. 44, no. 3, pp. 55-63, 1996. 